\title{
Transgenic Tobacco Plants Expressing the Potato virus $X$ Open Reading Frame 3 Gene Develop Specific Resistance and Necrotic Ring Symptoms After Infection with the Homologous Virus
}

\author{
Ken Kobayashi, ${ }^{1}$ Silvia Cabral, ${ }^{1}$ Gabriela Calamante, ${ }^{2}$ Sara Maldonado, ${ }^{3}$ \\ and Alejandro Mentaberry ${ }^{1}$ \\ ${ }^{1}$ Instituto de Investigaciones en Ingeniería Genética y Biología Molecular, CONICET, and Facultad de \\ Ciencias Exactas y Naturales, UBA, Argentina; ' Instituto de Biotecnología, INTA (Castelar), and Facultad \\ de Ciencias Exactas y Naturales, UBA, Argentina; ${ }^{3}$ Facultad de Ciencias Exactas y Naturales, UBA, \\ Argentina \\ Submitted 9 April 2001; Accepted 12 July 2001.
}

\begin{abstract}
Tobacco plants were transformed with the open reading frame 3 gene from Potato virus $X$ (PVX) coding for the p12 protein. Although the transgenic plants exhibited a normal morphological aspect, microscopic examination revealed extensive alterations in leaf tissue structure. After being challenged with PVX, the transgenic plants showed resistance to PVX infection and formation of specific leaf symptoms consisting of concentric rings encircled by necrotic borders. These novel symptoms were accompanied by biochemical changes normally associated with the hypersensitive response (HR) and were absent in noninfected transgenic plants or in PVX-infected nontransgenic plants. No equivalent virus resistance was observed after inoculation with Tobacco mosaic virus or Potato virus $Y$, suggesting the presence of a specific resistance mechanism. Despite development of HR-like symptoms, systemic acquired resistance was not induced in PVX-infected p12 transgenic plants. No evidence of an RNA-mediated resistance mechanism was found.
\end{abstract}

Additional keywords: necrotic lesions, Potexvirus, triple gene block, virus movement.

Cell-to-cell movement of plant viruses occurs through plasmodesmata (PD) in a process mediated by virus-encoded movement proteins (MPs) (Carrington et al. 1996; Deom et al. 1992; Lucas and Wolf 1999). In members of the Carlavirus, Furovirus, Hordeivirus, and Potexvirus genera, as well as in several unassigned viruses of the Simbdis virus-like superfamily, MPs and movement-associated proteins are encoded by a module of three partially overlapping open reading frames (ORFs) known as the triple gene block (TGB) (Beck et al. 1991; Forster et al. 1988; Morozov et al. 1989; Mushegian

Corresponding author: A. Mentaberry; Address: INGEBI-CONICET, Vuelta de Obligado 2490, (1428) Buenos Aires, Argentina; Telephone: +5411 4783 2871; Fax: +5411 4786 8578;

E-mail: amenta@dna.uba.ar and Koonin 1993). Involvement of the TGB proteins in viral movement was demonstrated by directed mutagenesis of individual TGB ORFs (Beck et al. 1991) and by functional complementation of movement-defective viruses in transgenic plants expressing TGB products (Bleykasten-Grosshans et al. 1997; Lough et al. 1998; Morozov et al. 1997; Verchot et al. 1998).

In the genus Potexvirus, TGB proteins are encoded by ORF2 to ORF4 (Skryabin et al. 1988). ORF2 MPs have molecular sizes of 24 to $28 \mathrm{kDa}$ and contain a conserved motif present in NTPases and helicases (Gorbalenya et al. 1988; Kalinina et al. 1996; Rouleau et al. 1994). ORF2 MPs from Potato virus $X$ (PVX) and White clover mosaic virus (WCIMV) accumulate at high levels in infected cells and induce an increase of the PD size exclusion limit (SEL) (Angell et al. 1996; Lough et al. 1998). Microinjection experiments with fluorophore-labeled ORF2 MP from WCIMV demonstrated that this MP is able to traffic through PD of neighboring cells (Lough et al. 1998). It was recently reported that movement of the PVX p25 MP might be regulated by interactions with other viral proteins (Yang et al. 2000). In the cases of Foxtail mosaic virus and PVX, it was also shown that ORF2 MPs have in vitro ATP- and RNA-binding activities (Kalinina et al. 1996; Rouleau et al. 1994). ORF2 MPs from different potexviruses were localized in the cytoplasm, both in the soluble fraction and in laminated inclusion bodies (Chang et al. 1997; Davies et al. 1993). Nevertheless, recent observations of WClMV- and Peanut clump virus (PCV)-infected cells suggest that small amounts of these proteins might be associated with the plasmodesmal channels during virus infection (Erhardt et al. 1999; Lough et al. 1998).

ORF3 and ORF4 encode proteins with molecular weights ranging between 11 to 14 and 6 to $10 \mathrm{kDa}$, respectively (Koonin and Dolja 1993; Morozov et al. 1991a; Zhou and Jackson 1996). ORF3 proteins contain a conserved hydrophilic sequence flanked by two highly hydrophobic domains, whereas ORF4 proteins contain a single hydrophobic domain close to their $\mathrm{N}$ termini (Morozov et al. 1987, 1989, 
1991b). In agreement with this, the small TGB proteins remained associated with membranous fractions in in vitro translation assays directed by PVX genomic RNA (Morozov et al. 1990), and immunodetection of PVX p8 revealed a cell wall localization, both in infected and in transgenic plants (Hefferon et al. 1997). Microinjection experiments performed in plants expressing WCIMV ORF3 and ORF4 demonstrated that none of the respective proteins are able to increase the plasmodesmal SEL (Lough et al. 1998). In the cases of hordeiviruses and potexviruses, coexpression of ORF3 and ORF4 proteins tagged with green fluorescent protein showed that the subcellular localization of ORF3 protein changes according to the presence or absence of ORF4 protein (Solovyev et al. 2000). It was suggested that the small TGB proteins could act as docking proteins to assist virus passage through PDs. However, the function of these proteins remains unclear.

Different experimental approaches showed that two subgenomic RNAs (sgRNAs) are responsible for translation of the entire TGB in members of the Hordeivirus, Furovirus, and Potexvirus genera (Morozov et al. 1991a; Verchot et al. 1998; Zhou and Jackson 1996). Thus, using in vitro translation and in vivo complementation assays, it was demonstrated that the PVX p25 MP is expressed from a 2.1-kb monocistronic sgRNA, whereas PVX $\mathrm{p} 12$ and $\mathrm{p} 8$ proteins are translated from a 1.4-kb bicistronic sgRNA (Morozov et al. 1991a; Verchot et al. 1998). Translation of the second and third TGB ORFs might occur by a mechanism involving leaky ribosome scanning (Verchot et al. 1998). It was suggested that this translational strategy and the strongly conserved organization of the TGB have important implications in the regulation of
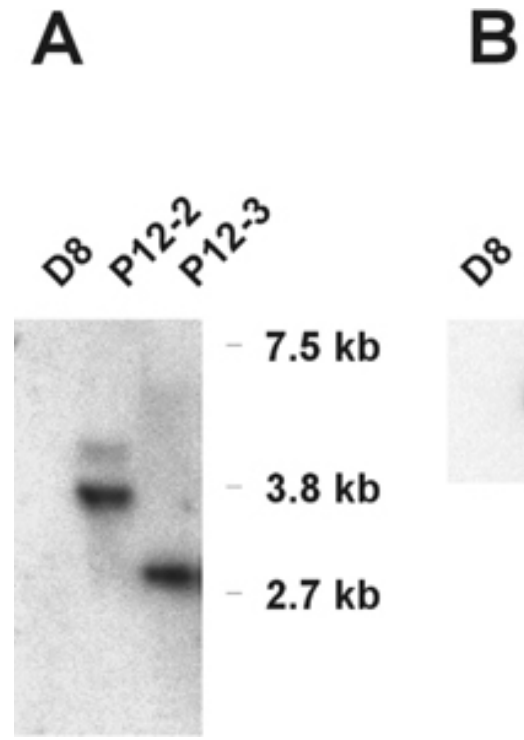

Fig. 1. Characterization of tobacco p12 lines. A, Southern blot analysis of lines p12-2 and p12-3. Ten micrograms of total DNA was digested with HindIII and subjected to electrophoresis. The blot was probed with a ${ }^{32} \mathrm{P}$-labeled cDNA fragment comprising Potato virus $X$ (PVX) open reading frame (ORF) 3 and ORF4. B, Northern blot analysis of lines p12-3 and p12-4. Total RNA from transgenic lines and Nicotiana tabacum cv. Xanthi D8 NN controls (D8) was obtained at 13 weeks postgermination and probed with a $\mathrm{P}^{32}$-labeled cDNA fragment comprising PVX ORF3 and ORF4. Five micrograms of total RNA was loaded in each lane. The arrow indicates the band corresponding to ORF3 mRNA. gene expression (Bleykasten-Grosshans et al. 1997; Verchot et al. 1998).

In addition to TGB proteins, it was demonstrated that the presence of viral coat protein $(\mathrm{CP})$ constitutes an absolute requirement for potexviral cell-to-cell movement (Chapman 1992; Forster et al. 1992; Lough et al. 1998; Santa Cruz et al. 1998). Immunolocalization of CP in PVX-infected cells showed that it was partially localized to PD (Oparka et al. 1996). Concomitant accumulation of fibrillar material into plasmodesmal channels suggested the formation of virionlike particles (Santa Cruz et al. 1998). Recent work by Lough and colleagues (2000) suggested that virus movement through PD involves specific ribonucleoprotein complexes.

Sequences coding for TGB proteins have been expressed in transgenic plants with variable results. Thus, transgenic plants expressing WCIMV ORF3 protein mutated in its hydrophilic domain showed resistance to several WClMV strains, PVX, and Potato virus $S$ (PVS) (Beck et al. 1994). Similarly, transgenic plants expressing a mutated version of PVX p12 showed resistance to PVX, Potato aucuba mosaic virus, PVS, and Potato virus $M$ (Seppanen et al. 1997), and tobacco plants expressing the native form of the PVX p24 MP showed altered phenotype and specific resistance to Tobacco mosaic virus (TMV)—but not to PVX (Ares et al. 1998). Also, coinfection with amplicons expressing the third TGB genes of Beet necrotic yellow vein virus (BNYVV) or PCV blocked symptom formation in tobacco leaves inoculated with BNYVV (Bleykasten-Grosshans et al. 1997). From these results, it was proposed that the unregulated expression of TGB proteins might be interfering with endogenous components required for normal virus movement (Ares et al. 1998; Beck et al. 1994; Bleykasten-Grosshans et al. 1997). Alternatively, expression of MPs might induce some kind of constitutive defense response. Indeed, the avirulence determinants for two natural resistance genes, $\mathrm{Nb}$ and $t m 2$, were localized in viral MPs (Malcuit et al. 1999; Meshi et al. 1989; Weber and Pfitzner 1998).

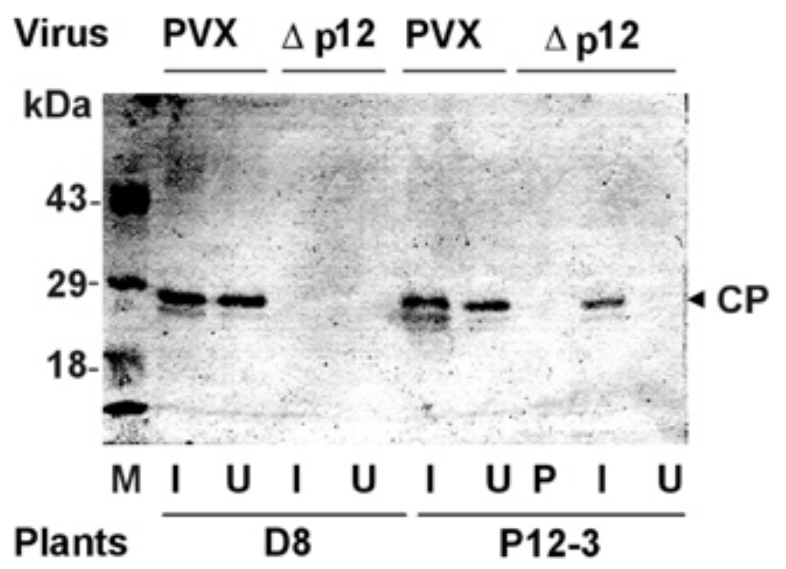

Fig. 2. trans Complementation assay of PVX $\Delta \mathrm{p} 12$ inoculated in $\mathrm{p} 12$ plants. Nicotiana tabacum cv. Xanthi D8 NN (D8) and p12-3 (p12-3) plants were inoculated with either pPVX3 $(\mathrm{PVX})$ or pPVX $\Delta \mathrm{p} 12(\Delta \mathrm{p} 12)$ in vitro transcribed RNA. At 14 days postinfection (dpi), total protein extracts from the inoculated leaves were prepared and analyzed in Western blots using polyclonal antibodies to the Potato virus $X$ (PVX) coat protein $(\mathrm{CP})$. M, molecular weight markers; I, extract from inoculated leaf; U, extract from first upper noninoculated leaf; and P, extract from preinoculated leaf. The arrowhead indicates the band corresponding to PVX CP. 
In this work, tobacco plants were transformed with the native sequence of the PVX ORF3 gene under regulation of the Cauliflower mosaic virus $35 \mathrm{~S}$ promoter. It was observed that PVX inoculation induced necrotic lesions resembling a mild form of hy-
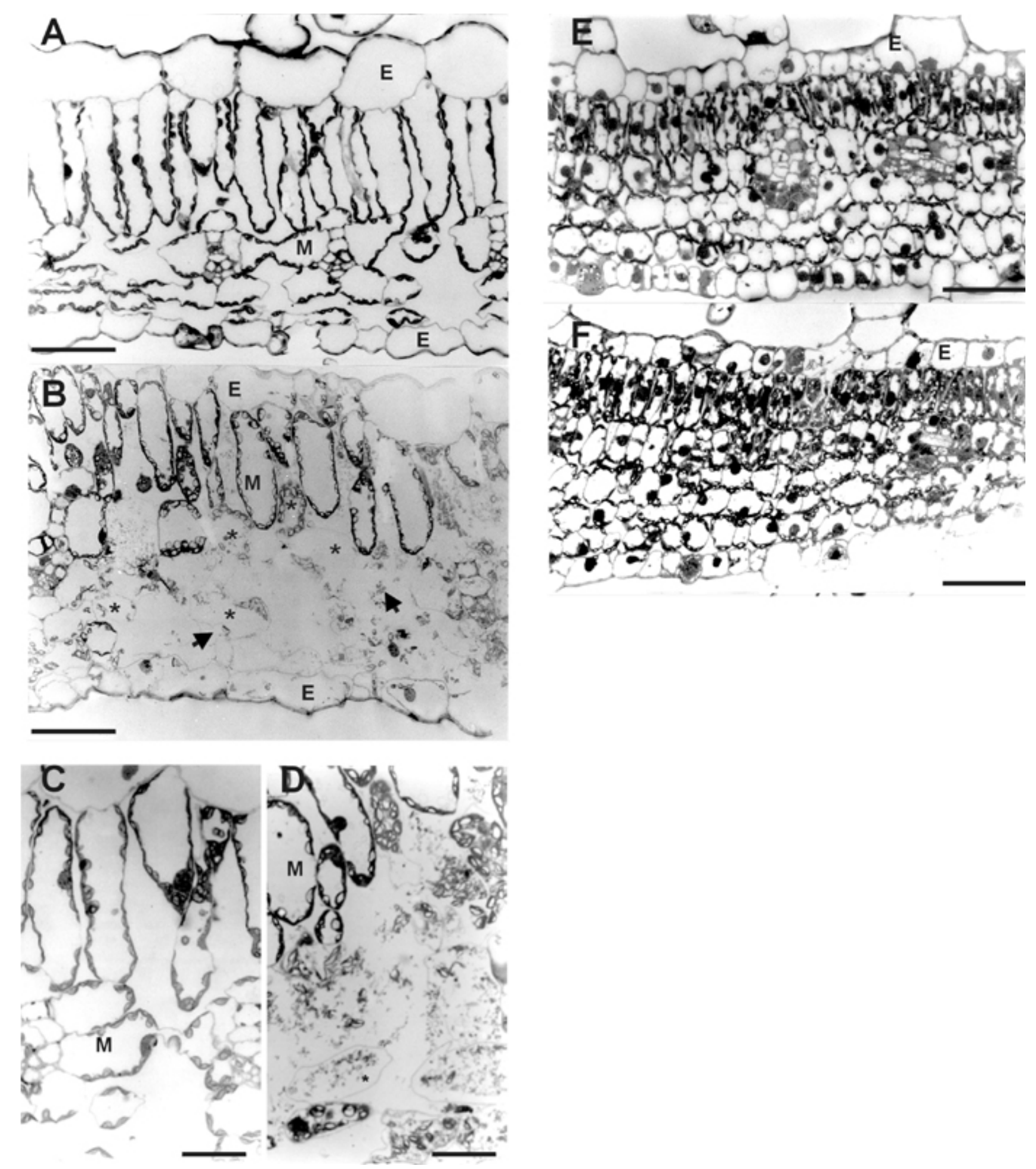

persensitive response (HR) in both inoculated and systemic leaves. These novel symptoms ultimately led to a kind of resistance that apparently combines progressive restriction of virus movement and induction of genes involved in a local defense response.

Fig. 3. Transverse leaf sections of A and C, Nicotiana tabacum cv. Xanthi D8 NN and B and D, p12-3 plants. Samples were collected from the third fully expanded leaves at 13 weeks postgermination. $\mathbf{E}$ and $\mathbf{F}$, Leaf sections corresponding to the second immature leaves of control and p12-3 plants, respectively. Arrows show altered tissue regions. A, B, E, and F, Bars $=100 \mu \mathrm{m}$ and $\mathbf{C}$ and $\mathbf{D}$, bars $=30 \mu \mathrm{m} . \mathbf{E}=$ epidermal cells, $\mathbf{M}=$ mesophyll cells, and $*=$ cells exhibiting advanced stages of degradation. 


\section{RESULTS}

\section{Characterization of transgenic plants expressing PVX ORF3.}

Southern blot analysis of five p12 lines (p12-2, p12-3, p124 , p12-13, and p12-101) confirmed the integration of a single copy of the ORF3 sequence in most of them. Analysis of lines p12-2 and p12-3 is shown in Figure 1A. Expression of transgenic mRNA was confirmed by Northern blot analysis (Fig. 1B). Attempts to detect the presence of the p12 protein in extracts of transgenic plants were impeded by the lack of suitable antibodies. Nevertheless, presence of the p12 protein in transgenic plants was deduced from trans complementation assays using the PVX $\Delta \mathrm{p} 12$ defective mutant. This virus was able to replicate normally in tobacco BY-2 protoplasts (data not shown). As shown in Figure 2, PVX $\Delta$ p12 was able to infect inoculated leaves in line p12-3, but failed to infect nontransgenic plants. Back-inoculation with extracts from PVX $\Delta \mathrm{p} 12-$ infected p12 plants failed to infect nontransgenic plants, indicating the absence of recombination to the wild-type genome (data not shown).

The phenotype of p12 plants was undistinguishable from that of nontransgenic controls at the whole-plant level. Nevertheless, when cuts from mature leaves were examined by light microscopy, extensive cell disruption was found in localized regions of the mesophyll, resulting in broad intercellular spaces filled with disorganized cytoplasm and accumulations of cell debris (Fig. 3B). Other cells, presumably representing intermediate stages of this process, exhibited massive organelle degradation and progressive reduction of cell walls (Fig. 3D). This altered tissue structure became apparent in fully expanded mature leaves, but was absent in younger leaves (Fig. $3 F)$. No histological abnormalities were observed in shoots or roots (data not shown).

\section{Development of atypical necrotic symptoms.}

Under normal conditions, strain CP2 of PVX only induces a mild mosaic in control tobacco plants. In contrast, infection of transgenic p12-2, p12-3, and p12-101 lines with PVX initially produced small chlorotic spots that expanded later to form chlorotic rings enclosing areas of green tissue. As rings developed, new chlorotic spots arose in their center. These spots progressed further to give rise to concentric rings (Fig. 4A). In more advanced stages, some individual outer rings became fused with each other and eventually stopped growing. At this point, symptoms consisted mainly of two to three concentric rings limited by a thin necrotic border (Fig. 4A and B). Similar concentric rings were observed in neighboring leaves following the progress of viral spreading. Since development of these symptoms suggested the presence of a defense mechanism, PVX accumulation was measured by enzyme-linked immunosorbent assay (ELISA) in inoculated and systemic leaves. Virus level in inoculated leaves was statistically the same in both control and p12-3 plants (data not shown). However, virus accumulation was significantly lower in upper, noninoculated leaves of p12-3 plants than in control leaves 2 weeks after infection (Fig. 4C). In correlation with this, a decrease in the number of lesions (or even a complete absence of symptoms) was observed in younger leaves of these transgenic plants (data not shown). Similar results were observed in the R1 progeny of lines p12-2 and p12-101 (Table 1). These two lines were selected because they exhibited a higher accumulation of transgenic RNA in Northern blot analysis (data not shown). PVX accumulation, as judged by the level of viral CP, was similar in nontransgenic and p12-3 protoplasts (Fig. 5), suggesting that virus replication was not affected in transgenic plants.
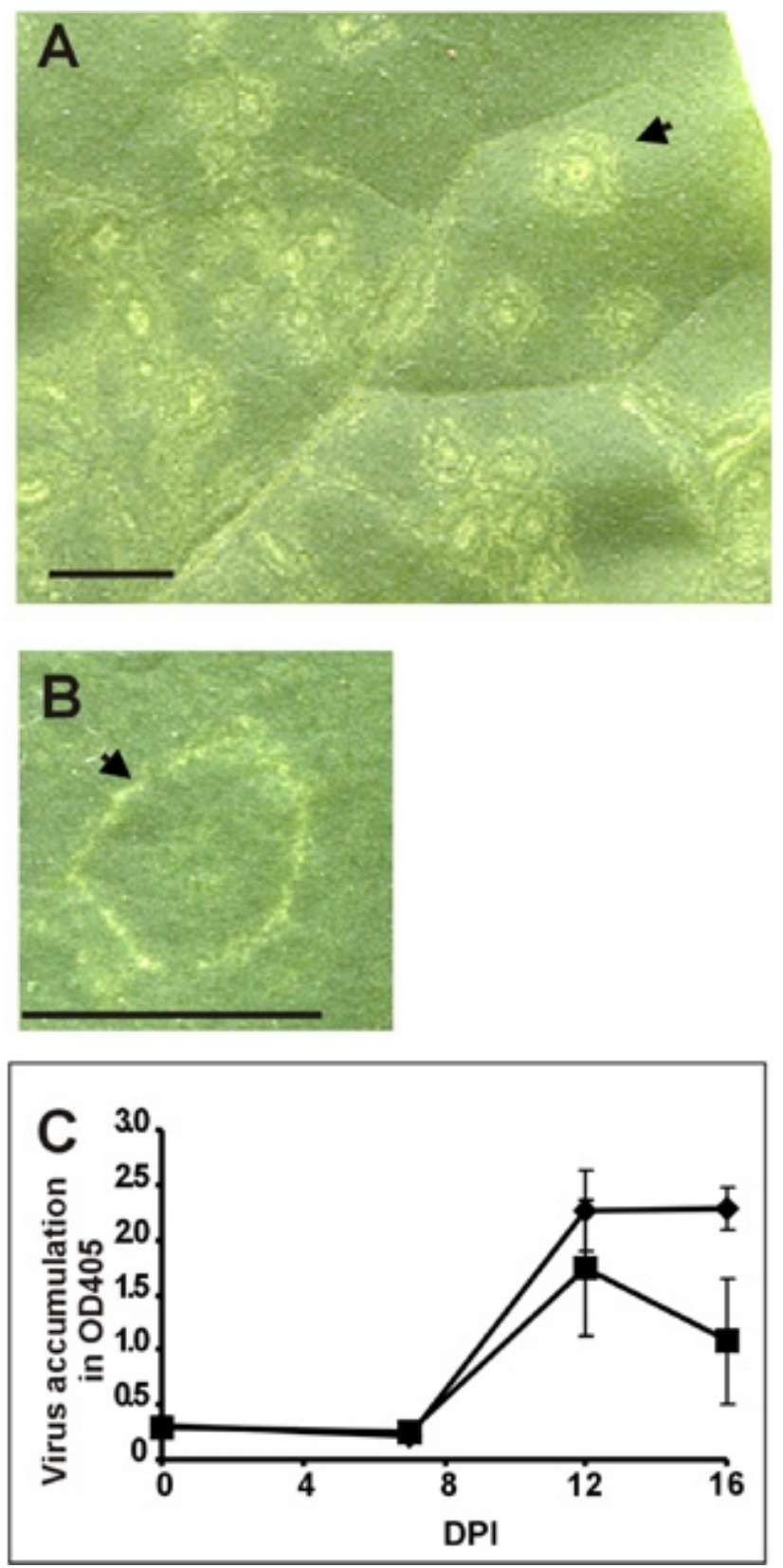

Fig. 4. Symptoms and Potato virus $X(\mathrm{PVX})$ infection course in $\mathrm{p} 12$ plants. A, Representative symptoms in a PVX-infected p12-3-inoculated leaf at 16 days postinfection (dpi). Bar $=1 \mathrm{~cm}$. B, Individual ring symptom in the same leaf. Bar $=5 \mathrm{~mm}$. C, PVX accumulation in p12-3 plants. Five to eight individual R2 transgenic plants or control plants were challenged with PVX-infected tobacco sap at time 0. Viral accumulation in the third upper leaves was monitored by enzyme-linked immunosorbent assay at the indicated dpi. Vertical bars represent standard deviations. Data shown correspond to a representative experiment. The assay was repeated four times with similar results. tabacum cv. Xanthi D8 NN plants; $\mathbf{\square}=$ p12-3 plants. 
To establish whether other viruses could induce this response, lines p12-3, p12-2, and p12-101 were inoculated with TMV or Potato virus $Y$ (PVY). No significant differences in the infection course were found between control and p12 plants after TMV or PVY inoculation (data not shown). Thus, the resistance observed in PVX-infected p12 plants seems to be specifically induced by PVX. To explore the possible participation of an RNA-mediated protection mechanism (Ruiz et al. 1998), a Northern blot analysis was conducted in the upper noninoculated leaves of infected and healthy p12-3 plants. A comparative estimation of ORF3 hybridization signals was made by image scanning of the corresponding bands. Relative band densities showed a similar accumulation of ORF3 transcripts in infected and healthy plants, indicating the absence of specific mRNA degradation (Fig. 6). A prominent smear of viral RNA was present in both PVX-infected transgenic and nontransgenic plants. The amount of viral RNA was considerably lower in p12 plants than in the corresponding controls (Fig. 6A), as it would be expected in the presence of virus resistance. The decline observed in virus RNA accumulation was consistent with the results shown in Figure 4 and Table 1.

\section{PVX-infected p12 plants developed HR-like lesions.}

To investigate whether the necrotic lesions observed in PVX-infected p12 plants are indicative of some kind of HR, callose and lignin accumulations were determined in symptomatic leaf samples. As shown in Figure 7A, callose accumulation was observed in mesophyll cells overlapping the necrotic lesions. In addition, as shown by Safranine staining, accumulation of lignin was also observed in lesion-containing sections. On the other hand, accumulation of callose or lignin was not detected in healthy transgenic plants in either infected or healthy control plants (data not shown). Observation of necrotic lesions under UV light revealed the presence of strong

Table 1. Resistance to Potato virus $X(\mathrm{PVX})$ in $\mathrm{R} 1$ transgenic lines ${ }^{\mathrm{a}}$

\begin{tabular}{ccccccc}
\hline & \multicolumn{7}{c}{ Virus accumulation (OD $\mathbf{O D 5})$} \\
\cline { 2 - 7 } Plants & 0 dpi & 7 dpi & 13 dpi & 16 dpi & 21 dpi & 27 dpi \\
\hline D8 & & & & & \\
1 & 0.155 & 0.201 & 0.199 & 1.131 & 1.186 & 1.201 \\
2 & 0.148 & 0.202 & 0.201 & 1.131 & 1.197 & 1.221 \\
3 & 0.158 & 0.240 & 0.203 & 1.231 & 1.183 & 1.169 \\
p12-101 & & & & & & \\
1 & 0.156 & 0.169 & 0.181 & 0.200 & 0.207 & 0.154 \\
2 & 0.155 & 0.178 & 0.160 & 0.221 & 0.199 & 0.159 \\
3 & 0.150 & 0.181 & 0.163 & 0.151 & 0.191 & 0.171 \\
4 & 0.151 & 0.199 & 0.164 & 0.153 & 0.218 & 0.163 \\
5 & 0.153 & 0.193 & 0.163 & 0.150 & 0.166 & 0.184 \\
6 & 0.156 & 0.222 & 0.174 & 0.162 & 0.194 & 0.206 \\
7 & 0.150 & 0.246 & 0.187 & 0.180 & 0.170 & 0.192 \\
8 & 0.166 & 0.219 & 0.206 & 0.170 & 0.181 & 0.169 \\
p12-2 & & & & & & \\
1 & 0.155 & 0.168 & 0.155 & 0.220 & 0.220 & 0.145 \\
2 & 0.173 & 0.169 & 0.152 & 0.217 & 0.229 & 0.151 \\
3 & 0.154 & 0.189 & 0.712 & 0.152 & 0.350 & 0.154 \\
4 & 0.162 & 0.187 & 1.097 & 0.941 & 1.034 & 0.158 \\
5 & 0.160 & 0.212 & 0.192 & 0.180 & 0.998 & 0.181 \\
\hline
\end{tabular}

${ }^{a} \mathrm{R} 1$ transgenic lines p12-101 and p12-2 were challenged with PVXinfected sap at 0 time. Viral accumulation in the third upper leaves was monitored by enzyme-linked immunosorbent assay (ELISA) at the indicated dpi. Data shown correspond to the optical density at $405 \mathrm{~nm}$ $\left(\mathrm{OD}_{405}\right)$ measurements in ELISA plates. autofluorescence, indicating local accumulation of phenolic compounds (Fig. 7B). Autofluorescence was not observed in leaves of PVX-infected control plants or healthy p12 plants. In contrast to the HR-like lesions described above, inoculation with the PVX $\Delta$ p12 defective mutant induced chlorotic spots 3 to $4 \mathrm{~mm}$ in diameter.

Induction of pathogenesis-related proteins (PRs) has also been associated with development of HR (Bol et al. 1990). Thus, a Northern blot analysis was performed to investigate the presence of PR mRNAs in PVX-infected p12 leaves. As shown in Figure 8A and B, PR1a, PR2, and PR3 mRNAs were strongly induced in PVX-infected transgenic plants, while they were undetectable in healthy p12 plants and in both infected and healthy control plants. A weak PR1a and PR2 expression was also detected in the upper noninoculated leaves of PVX-infected p12 plants at 16 days postinfection (dpi). No presence of virus was detected in these leaves (Fig. 8B). As previously reported (Brederode et al. 1991), acidic PRs were highly induced in inoculated and upper noninoculated leaves of TMV-infected plants (Fig. 8B).

\section{Systemic acquired resistance (SAR) is not established in PVX-infected p12 plants.}

The presence of HR-like lesions and the weak PR expression detected in the upper noninoculated leaves prompted us to investigate whether SAR is established in PVX-infected p12 plants. To test this, control and transgenic p12-3 plants were firstly inoculated in the lower leaves with either PVX or TMV, and then reinoculated in the upper leaves with TMV after 10 days of the primary infection. At this stage, HR-like (PVX-inoculated) or HR (TMV-inoculated) lesions were clearly visible on primary inoculated leaves. Establishment of SAR was determined by measuring the size of the TMV-induced lesions developed in reinoculated upper leaves (Ross 1961). As shown in Table 2, reduction in lesion size indicated establishment of SAR in nontransgenic and p12 plants after primary inoculation with TMV. In contrast with this, nontransgenic and p12 plants failed to develop SAR after primary inoculation with PVX.

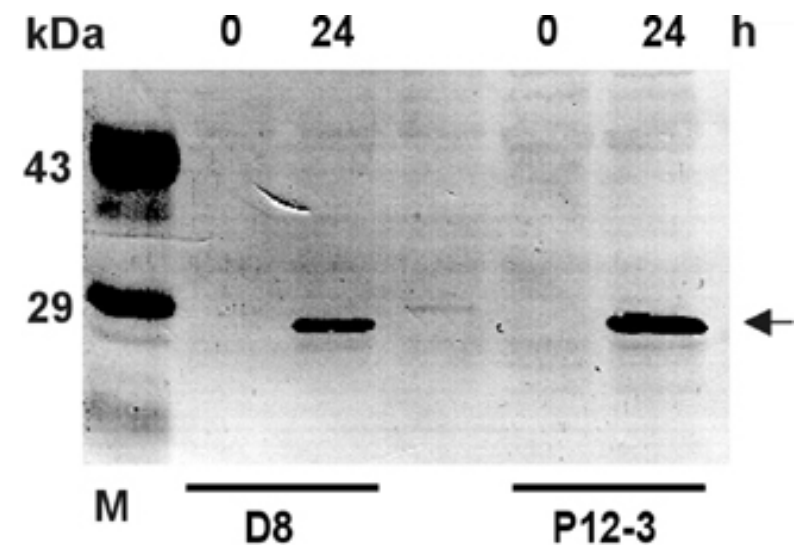

Fig. 5. Replication of pPVX3 RNA transcripts in protoplasts from Nicotiana tabacum cv. Xanthi D8 NN (D8) or p12-3 (p12-3) plants. Total protein extracts were analyzed in Western blots at 0 and $24 \mathrm{~h}$ postinfection with polyclonal antibodies to the Potato virus $X(\mathrm{PVX})$ coat protein (CP). M, molecular weight standards. The arrow indicates the band corresponding to the PVX CP. 


\section{DISCUSSION}

Tobacco plants were transformed with the PVX ORF3 gene. Expression of ORF3 mRNA was confirmed in different transgenic lines by Northern blot analysis, but no direct evidence for the presence of $\mathrm{p} 12$ protein could be obtained. Antibodies raised against Escherichia coli-expressed p12 were able to recognize p12 in bacterial extracts, but failed to detect p12 in extracts of transgenic or PVX-infected tissue (data not shown). Nevertheless, the presence of p12 in transgenic plants was inferred from complementation assays with an ORF3-deleted version of PVX (pPVX $\Delta \mathrm{p} 12)$. Since the defective virus was able to move in p12 plants, but not in nontransgenic plants, we concluded that the ORF3 mRNA was correctly translated into functional p12. Similar results were previously reported by Verchot and colleagues (1998) using a PVX ORF3-defective version.

Major morphological and physiological parameters of p12 plants were undistinguishable from those of control plants, and only a slight delay in growth was occasionally observed in some transgenic lines. However, microscopic observation of transgenic leaf tissue showed an abnormal histological structure characterized by the presence of broad intercellular spaces containing cell debris and partially degraded parenchyma cells. Both the cell walls and the subcellular organization of the remaining parenchyma cells, as well as those of epidermal and vascular components, remained normal. To eliminate the possibility that these structures originated during the preparation of the leaf samples, two different fixation procedures were performed. In each case, identical observations were made using different leaf samples and two transgenic lines, strongly suggesting that the abnormal histological structures constitute a preexistent feature of mature transgenic leaves. Moreover, the lack of alterations in younger immature leaves and the presence of partially degraded cells with very thin walls in mature tissues suggest that the abnormal histological structures found in p12 plants are progressively established, accompanying leaf development.

As with most PVX strains, inoculation with the CP2 strain normally induces a mild form of mosaic in control tobacco plants. In contrast, inoculation with the strain CP2 produced a series of novel symptoms in p12 transgenic plants. These symptoms included development of concentric rings encircled by an outer necrotic border that arose in both inoculated and the upper noninoculated leaves at 7 to 9 dpi. Development of necrotic rings followed viral spread into noninoculated tissues, but their number progressively decreased, to finally disappear, in younger upper leaves. These symptoms were not induced in p12 plants inoculated with PVY or TMV, suggesting that they constitute a specific response to PVX. Close examination of concentric rings revealed accumulation of compounds typically associated with HR, such as callose, lignin, and phenolic compounds (Ponz and Bruening 1986). In addition, it was found that accumulation of PR1a, PR2, and PR3 mRNAs was strongly induced in PVX-infected leaves. These acidic PRs are normally produced as part of local and systemic responses to different pathogens, including viruses, bacteria, and fungi, but are not expressed in response to abiotic stresses (Brederode et al. 1991).

Typically, HR results in the rapid establishment of local lesions in inoculated leaves. Instead, the symptoms observed in p12 plants appeared relatively late and included the development of systemic lesions. Remarkably, although PVX is able to move to systemic tissues in p12 plants, a consistent decrease in virus accumulation was found in the upper leaves after 16 dpi. In contrast, virus accumulation continually increased in control plants until reaching a plateau at 16 dpi. No differences in virus accumulation were found between control and transgenic plants in PVY or TMV infections. Necrotic ring development could also be related to the abnormal structure of mature leaves in p12 plants. Nevertheless, no sponta-
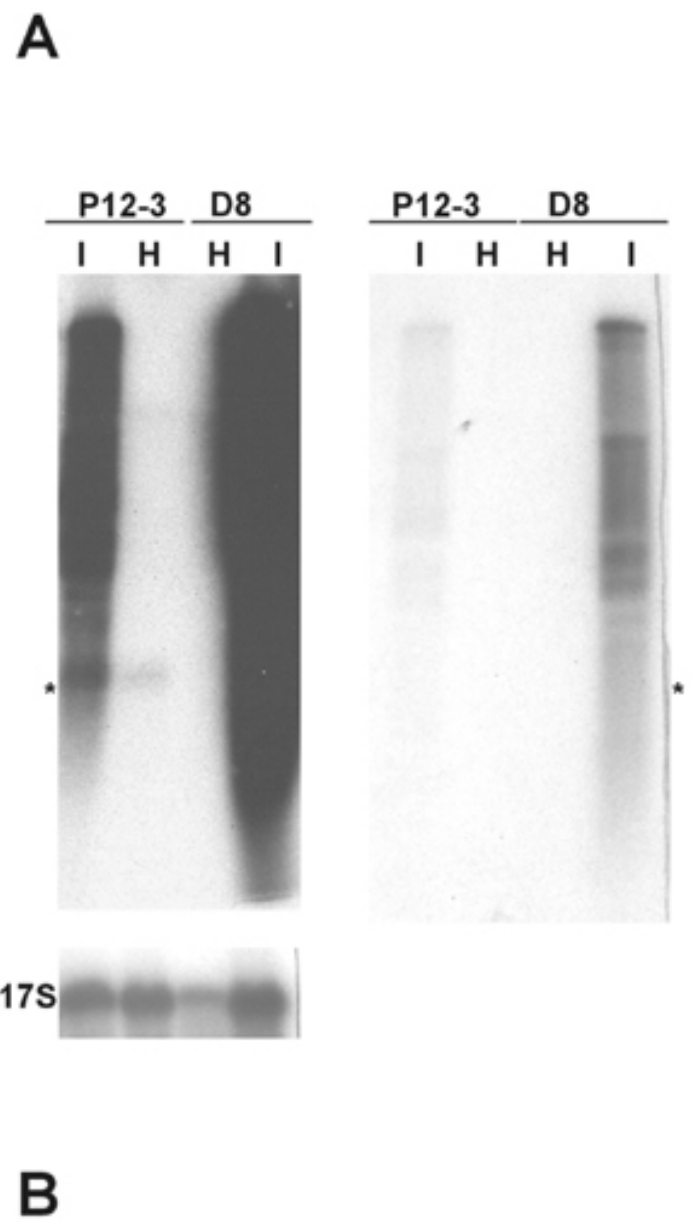

\begin{tabular}{|c|c|c|c|}
\multicolumn{5}{|c}{ Arbitrary Units } \\
\hline & ORF3 & 17 S rRNA & ORF3/17S \\
\hline $\mathrm{p} 12-3 / 1$ & 1223 & 6489 & 0.188 \\
\hline $\mathrm{p} 12-3 / \mathrm{H}$ & 1271 & 6508 & 0.195 \\
\hline
\end{tabular}

Fig. 6. Comparative accumulation of open reading frame (ORF) 3 transcripts after Potato virus $X(\mathrm{PVX})$ infection. Northern blot analysis was carried out with total RNA extracted from healthy $(\mathrm{H})$ or PVX-infected (I) Nicotiana tabacum cv. Xanthi D8 NN (D8) or p12-3 (p12-3) plants. Samples were collected from the third upper leaves at 14 days postinfection. The same blot was hybridized with a ${ }^{32} \mathrm{P}$-labeled ORF3-specific probe, stripped, and rehybridized with a $17 \mathrm{~S}$ rRNA probe. Asterisk indicates the position corresponding to ORF3 transcripts. A, Autoradiographies of the same blot after 12-h (left) and 4-h (right) exposures. Rehybridization of the same blot with a 17S rRNA probe (17S) is shown in the lower insert. B, Comparative densitometric values corresponding to ORF3 and 17S rRNA bands and ORF3/17S rRNA ratios for PVXinfected and healthy p12 plants. The assay was repeated twice with similar results. 

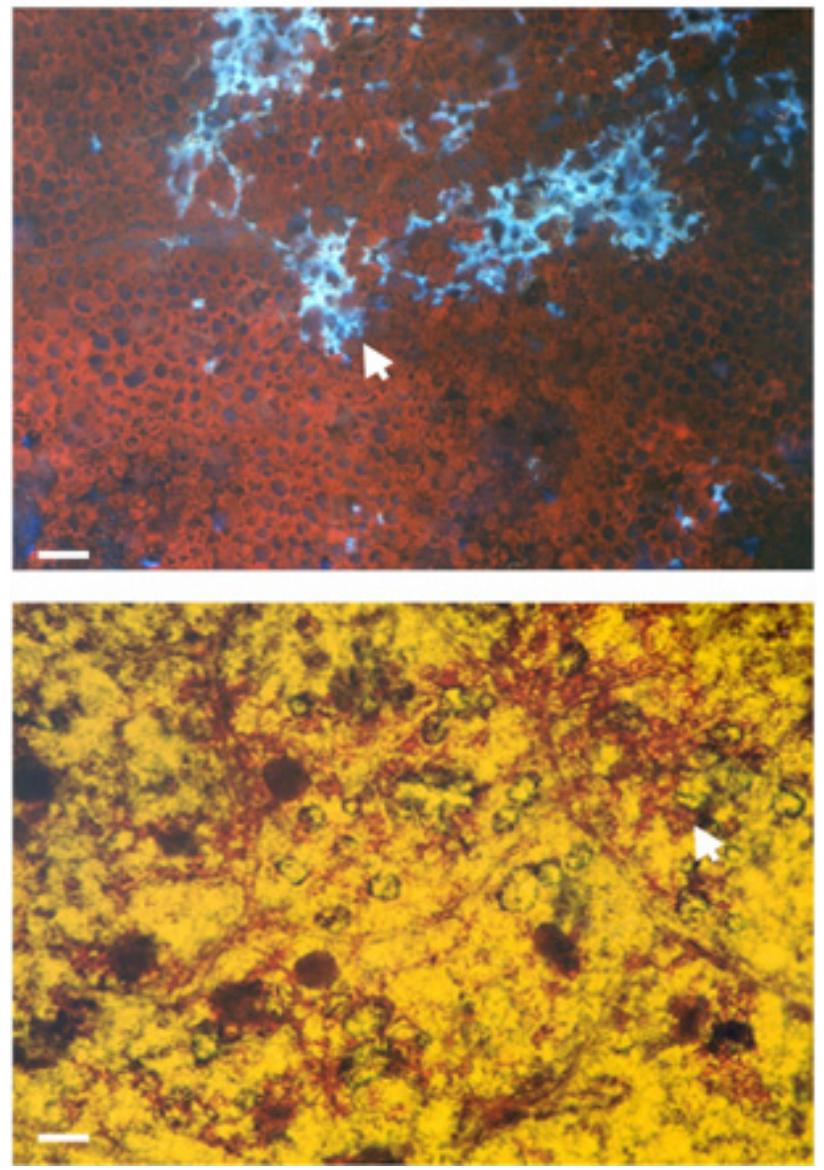

\section{B}

H

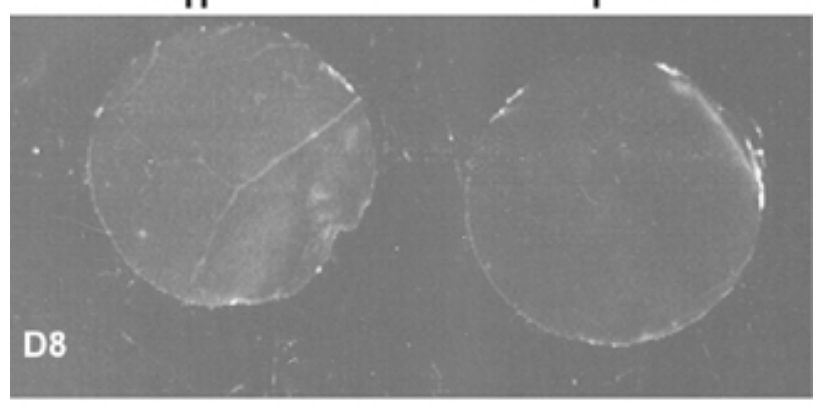

H

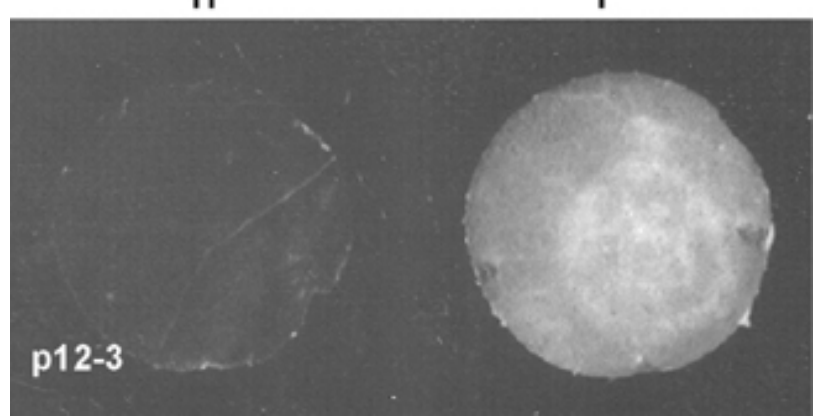

neous symptom formation was detected in noninoculated $\mathrm{p} 12$ plants, whereas young p12 leaves-which exhibit a normal histological structure-readily developed lesions when infected with PVX (data not shown). The unusual alterations found in the parenchyma of mature p12 leaves had no effect on the course of PVY or TMV infections.

Since resistance in p12 plants was observed only after inoculation with PVX, we conclude that this response is specific and simultaneously requires expression of transgenic p12 and PVX replication. As inferred from the transfection assays of p12 protoplasts, the rate of PVX replication would not be significantly affected in transgenic plants. Thus, although the p12 level could not be measured, it is reasonable to assume that the total amount of p12 is higher in PVX-infected p12 plants than in control plants and would be the primary factor leading to the appearance of HR-like symptoms. Interestingly, the level of viral resistance could not be correlated with transgenic mRNA expression in the different p12 lines. This suggests that the mechanism involved in virus resistance might be activated after surpassing a critical threshold of p12. It also suggests that overexpression of p12 might be deleterious to plant development and, consequently, might be negatively selected during plant transformation. On the same basis, the milder response observed after inoculation with $\mathrm{pPVX} \Delta \mathrm{p} 12$ could be interpreted as a consequence of lower p12 accumulation during the trans complementation assay.

HR development usually induces the establishment of SAR, a late and nonspecific systemic response involving the production of different kinds of defense proteins (Ryals et al. 1996). However, although PVX-infected p12 plants showed a weak systemic expression of PR mRNAs, they failed to develop induced resistance to TMV, as judged by the size of TMV-induced necrotic lesions in reinoculated upper leaves. The absence of systemic resistance suggests that the necrotic symptoms observed in p12 plants constitutes a particular case of response, including part of the mechanisms leading to classical HR, but lacking those involved in typical SAR induction. On the other hand, the possible presence of RNA-mediated resistance (i.e., posttranscriptional gene silencing; Ruiz et al. 1998) was discarded because no significant differences in transgenic RNA accumulation were observed in PVX-infected and healthy p12 plants. Moreover, PVX replication was not affected in p12 plants, and coinfection assays with PVX and PVY (encoding the HC-Pro protein, a putative suppressor of posttranscriptional gene silencing) showed no increase in PVX accumulation level (data not shown). In addition, a preliminary assay showed that PVX inoculation in mildly symptomatic upper leaves of preinfected p12 plants induces a normal course of infection.

Fig. 7. Callose, lignin, and phenolic compound accumulations in Potato virus $X$ (PVX)-infected p12-3 leaves. A, Infected leaf tissue stained with $0.1 \%$ Aniline Blue (upper panel, blue color) or $0.1 \%$ Safranine (lower panel, red color) showing deposits of callose and lignin (indicated with arrows), respectively, around hypersensitive response (HR)-like lesions. Bars $=70 \mu \mathrm{m}$. B, Healthy $(\mathrm{H})$ and PVX-infected (I) leaf disks $(1 \mathrm{~cm}$ in diameter) from Nicotiana tabacum cv. Xanthi D8 NN (upper panel) and p12-3 (lower panel) plants. Leaf disks were illuminated with a 365-nm UV light. Autofluorescence of phenolic compounds causes necrotic rings to appear as fluorescent white concentric rings. Samples were obtained at 16 days postinfection. 
The strongly conserved organization of TGB genes seems to be required to tightly regulate the synthesis of TGB proteins. In the genus Potexvirus and other viral groups, the two small TGB proteins are translated in very low amounts from a single sgRNA, and it is assumed that this determines synthesis of these proteins in a fixed stoichiometric ratio (Verchot et al. 1998). Therefore, accumulation of $\mathrm{p} 12$ relative to $\mathrm{p} 8$ after PVX inoculation might be critical to the outcome of infection in transgenic plants. Expression of native PVX and WCIMV ORF3 proteins was previously achieved by others in Nicotiana benthamiana and Solanum tuberosum (Beck et al. 1994; Seppanen et al. 1997), but no HR-like symptoms or other forms of resistance were reported after infection of transgenic plants with the homologous viruses. Since ORF3 proteins were translated from bicistronic mRNAs, which also include ORF4 genes, the two small TGB proteins were presumably synthesized at a constant ratio in both infected and uninfected plants (Beck et al. 1994; Seppanen et al. 1997). In at least two cases, ORF3 genes were individually expressed from constitutive promoters, but neither novel symptoms nor histological alterations were reported (Lough et al. 1998; Verchot et al. 1998). On the other hand, previous work by BleykastenGrosshans and colleagues (1997) showed that overexpression of BNYVV ORF3 protein induced atypical necrotic lesions in Chenopodium quinoa after inoculation with the same virus. In addition, overexpression of the third TGB protein (ORF4 protein) blocked spreading of BNYVV and development of infection symptoms in both $C$. quinoa and Beta macrocarpa. By analogy to the case of BNYVV ORF4 protein, we postulate that overexpression of PVX p12 protein might affect normal virus movement, inducing an attenuated form of $\mathrm{HR}$ in the host. The ORF3 sequence used in our work was transcribed from a strong promoter and, therefore, the $\mathrm{p} 12 / \mathrm{p} 8$ ratio was presumably much higher in PVX-infected plants than in noninfected plants. Thus, it could be hypothesized that excess of free p12 over a critical threshold is the primary determinant of symptom formation. Alternatively, due to the strong hydrophobic nature of p12, a higher expression of this protein might disturb normal membrane and/or plasmodesmal function in transgenic plants and, in turn, this altered state might trigger expression of HR-related components, though at a much slower rate and a lower level than in normal HR.

Recent work by Solovyev and colleagues (2000) showed that the second TGB proteins of Poa semilatent virus and PVX seem to be localized in the membranes of the endoplasmic reticulum and are diverted to peripheral cell bodies when coexpressed with the third TGB proteins of these viruses. Although the possibility of a direct interaction between the smaller TGB proteins was discarded, this strongly suggests that coregulated synthesis of both proteins is an important requirement for normal intercellular sorting during virus infection. Thus, exceeding amounts of p12 in transgenic plants could be relocalized by $\mathrm{p} 8$ and interact with yet-unknown plant factors, triggering host defense mechanisms. Further studies on the subcellular localization of PVX p12 and p8 in normal virus infection, as well as identification of the host factors interacting with these two proteins in transgenic and nontransgenic plants, will be necessary to clarify the molecular basis of the response described in this paper.

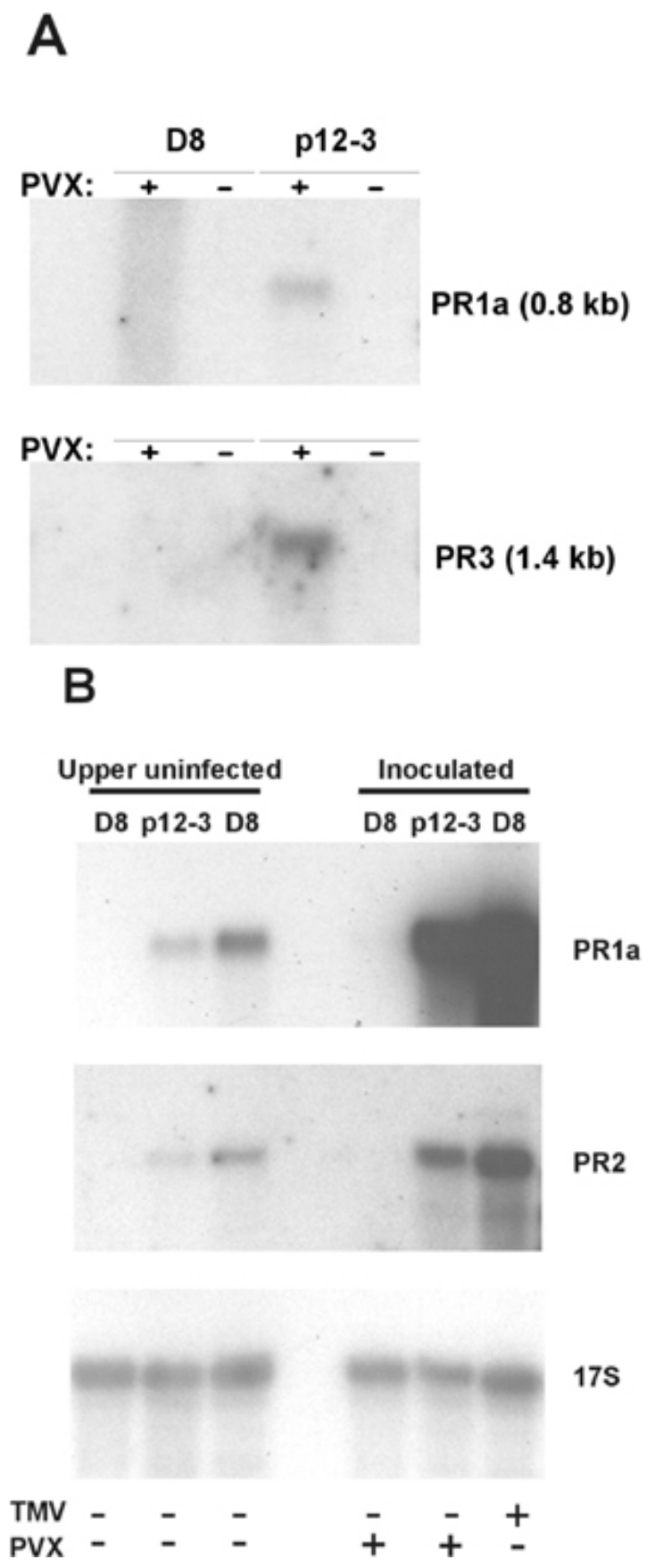

Fig. 8. Induction of pathogenesis-related protein (PR) mRNAs in Potato virus $X$ (PVX)-infected p12-3 transgenic plants. A, Total RNA extracts were purified from the third upper leaves at 14 days postinfection (dpi), concomitantly with the development of necrotic symptoms. Northern blot analysis was performed using specific ${ }^{32} \mathrm{P}$-labeled cDNA probes for tobacco PR1a and PR3. Five micrograms of total RNA was loaded in each lane. The blot was hybridized first with the PR1a probe. After stripping and washing, the same blot was rehybridized with the PR3 probe. D8, Nicotiana tabacum cv. Xanthi D8 NN plants; p12-3, p12-3 plants; $(+)$, PVX-infected plants; and (-), noninoculated healthy plants. Bands corresponding to the respective PRs are indicated. B, Northern blot assay corresponding to samples from inoculated leaves (Inoculated) and from upper leaves yet uninfected by PVX (Upper uninfected) at 16 dpi. Inoculated and upper leaves of Tobacco mosaic virus (TMV)-infected plants were used as positive controls for PR induction. Presence/absence of TMV or PVX was determined by Northern and/or Western blot assays and indicated by $(+)$ and $(-)$, respectively. 


\section{MATERIALS AND METHODS}

Virus isolates.

PVX strain CP2 was obtained from the International Potato Center (Lima, Peru). Cloning and sequencing of the respective genomic sequence (GenBank accession no. X55802) have been previously reported (Orman et al. 1990). A full-length copy of the PVX genome was obtained by assembling appropriate cDNA fragments (Calamante 1998). The resulting clone, named pPVX3, encompassing nucleotides 1 to 6,432 and a poly(A) tail of 24 residues, was ligated downstream of the T7 polymerase promoter and introduced into the $E$. coli vector pUC18 (New England Biolabs, Beverly, MA, U.S.A.). The pPVX3 was sequenced to confirm the absence of undesired mutations. The pPVX $\Delta$ p12 version, carrying a 108-nucleotide deletion in ORF3, was obtaind by further modification of the pPVX3 sequence. To this aim, a NheI/NheI fragment from pPVX3 (corresponding to positions 4,874 to 5,792 of the PVX genome) was subcloned into the pBS-SK+ vector in such a way that the NheI recognition sites were regenerated at both ends of the insert. A $X b a I$ digestion was then performed to delete the sequence between positions 5,254 and 5,363. After religation of both $X b a \mathrm{I}$ ends, the deleted NheI/NheI fragment was removed from pBS-SK+ and reintroduced into pPVX3 to replace the original sequence. The TMV U1 strain used in this work (common strain) was obtained from R. Beachy (Donald Danford Plant Science Center, St. Louis, MO, U.S.A.).

\section{Genetic constructions.}

A DNA fragment encoding PVX ORF3 and ORF4 was amplified by polymerase chain reaction (PCR) using plasmid $5 \mathrm{X} 41$ as a template (Orman et al. 1990) and the primers GGAATTCGATATCCCAACAATGTCCGCGCAGGGGCAT and GAATTCGATATCTTATCACTGGAAACTTAA to generate EcoRI sites at both ends of the PVX sequence. The PCR fragment was then ligated to the bacterial vector pCRII (Invitrogen, Carlsbad, CA, U.S.A.) to create pCRp12/p8. Digestion of pCRp12/p8 with BamHI and HinfI produced a 428-bp fragment containing the complete ORF3 sequence (positions 5,147 to 5,508 of the PVX genome). Directional cloning of this fragment into the corresponding sites of the plant expression vector pBI121 (Clontech, Palo Alto, CA, U.S.A.) gave rise to plasmid pBI/p12.

Table 2. Systemic response to secondary infection with Tobacco mosaic virus (TMV)

\begin{tabular}{lccc}
\hline & \multicolumn{3}{c}{ Primary inoculation } \\
\cline { 2 - 4 } Plants & Mock & TMV & PVX \\
\hline D8 & $4.6 \pm 0.593^{\mathrm{b}}$ & $2.7 \pm 0.504$ & $4.1 \pm 0.53$ \\
p12 & $4.6 \pm 0.709$ & $3.2 \pm 0.679$ & $4.3 \pm 0.692$ \\
\hline
\end{tabular}

${ }^{a}$ Systemic protection responses to TMV in Potato virus $X$ (PVX)infected p12 plants. Thirteen-week-old Nicotiana tabacum cv. Xanthi D8 NN (D8) and p12-3 (p12) plants were preinoculated in the fifth leaf with PVX, TMV, or phosphate buffer (Mock). Ten days later, the same plants were inoculated with TMV in the third upper leaf. Two plants per line were inoculated. Necrotic lesion sizes $(n=20)$ were measured 5 days after the secondary inoculation. Average lesion sizes from two independent experiments are indicated.

b TMV-induced secondary inoculation. Lesion size is indicated in millimeters \pm standard deviation. Each value represents the means of 20 lesions measured in two independent experiments.

\section{Plant transformation.}

N. tabacum cv. Xanthi D8 NN used to generate transgenic plants was obtained from Y. Chupeau (INRA, Versailles, France). Leaf disk explants were transformed via Agrobacterium spp. according to the procedure described by An and colleagues (1988). To ensure generation of independent transgenic plants, only one shoot per explant was selected. After performing NPTII activity assays to discard selection escapes, 15 kanamycin-resistant R0 plants were selected. Self-pollination of R0 and R1 plants and subsequent segregation analysis of kanamycin-resistant phenotypes allowed characterization of line p12-3 as homozygous for the npt II gene. Gene copy number was established by Southern blot analysis. Other p12 R1 lines showing different expression levels of transgenic RNA were selected for further experiments.

\section{Northern and Southern blot analyses.}

Total RNA for Northern blot analysis was extracted from tobacco leaves according to the procedure described by Verwoerd and colleagues (1989). Plant tissue was ground in liquid $\mathrm{N}_{2}$; extracted with a solution containing $10 \mathrm{mM}$ EDTA, $1 \%$ sodium dodecyl sulfate (SDS), $100 \mathrm{mM} \mathrm{LiCl}, 100 \mathrm{mM}$ Tris- $\mathrm{HCl}, \mathrm{pH} 8$; and mixed $(1: 1, \mathrm{vol} / \mathrm{vol})$ with water-equilibrated phenol, preheated at $80^{\circ} \mathrm{C}$. After centrifugation and chloroform extraction, total RNA was precipitated by incubation at $4^{\circ} \mathrm{C}$ in $2 \mathrm{M} \mathrm{LiCl}$, and then analyzed by electrophoresis in formaldehyde-containing agarose gels. ORF3 transcripts were quantitatively evaluated using NIH Scion Image software (Scion Corporation, Frederick, MD, U.S.A.). Relative hybridization signals were normalized according to S17 rRNA hybridization. Values for ORF3 bands were adjusted by subtracting the respective hybridization backgrounds. Total DNA for Southern blot analysis was extracted from tobacco using a DNA Easy Plant Prep Kit (Qiagen, Valencia, CA, U.S.A.) as instructed by the manufacturer. After digestion with appropriate restriction enzymes, aliquots of $10 \mu \mathrm{g}$ were analyzed in $0.8 \%$ agarose gels and transferred to Z-Probe Nylon membranes (BioRad, Hercules, CA, U.S.A.). Specific RNA or DNA sequences were detected by hybridization with ${ }^{32} \mathrm{P}$ labeled cDNA probes obtained with a Rad Prime DNA Labeling System kit (Gibco-BRL, Grand Island, NY, U.S.A.). The tobacco cDNA sequences used to study expression of PR1a, PR2, and PR3 mRNAs were kindly provided by E. Lam (Rutgers University, New Brunswick, NJ, U.S.A.). The rice cDNA sequence used to hybridize $17 \mathrm{~s}$ rRNA was kindly provided by J. Muschietti (INGEBI-CONICET, Buenos Aires, Argentina).

\section{Infection assays.}

PVX inoculum was obtained by homogenization of infected tobacco leaves in $0.1 \mathrm{M}$ phosphate buffer at a $10 \% \mathrm{wt} / \mathrm{vol} \mathrm{ra}-$ tio and each plant was inoculated with $100-\mu$ laliquots of this preparation. Viral RNA transcripts were synthesized in vitro from linearized plasmids pPVX3 and pPVX $\Delta \mathrm{p} 12 \mathrm{~A}$, following the protocol provided with the RiboMAX T7 RNA transcription kit (Promega, Madison, WI, U.S.A.) and adding 10\% ( vol/vol) dimethy sulfoxide and 0.6 mM Cap analog ( $\mathrm{m}^{7} \mathrm{GpppG}$; New England Biolabs, Beverly, MA, U.S.A.) to the reaction mixture. TMV infection assays were performed using a virion preparation purified as described by Padgett and Beachy (1993). Each infection assay included five to eight plants per line and was repeated at least four times. Eleven to thirteen 
weeks after seed germination, leaves in the upper third portion of the plant were mechanically inoculated with either $100 \mu \mathrm{l}$ of PVX sap extracts, 1 to $2 \mu \mathrm{g}$ of viral RNA, or 5 to $10 \mathrm{ng}$ of TMV-purified virions using Carborundum powder (330 grit; Fisher Scientific, Pittsburgh, PA, U.S.A.) as an abrasive. Leaves were then rinsed with tap water and plants were kept in a growth chamber under a 16-h light/8-h dark photoperiod. Sampling was performed in the third fully expanded upper leaf by punching the tissue with the cap of a 1.5-ml Eppendorf tube. Three samples from different regions of the leaf were collected for each plant.

\section{Electroporation of tobacco protoplasts.}

Protoplasts from N. tabacum cv. Xanthi D8 NN or transgenic p12 lines were obtained from leaves of in vitro cultured plants. For this, $1 \mathrm{~g}$ of tissue was incubated overnight at room temperature in a solution containing $0.015 \mathrm{~g}$ of cellulase R10 per $\mathrm{ml}$ and $0.002 \mathrm{~g}$ of macerase R10 per $\mathrm{ml}$ (Onozuka-Yakult, Tokyo, Japan) in $0.6 \mathrm{M}$ mannitol and $0.1 \%$ 2-( $N$-morpholino) ethanesulfonic acid, $\mathrm{pH}$ 5.8. Protoplasts were then filtered through a $300-\mu \mathrm{m}$-pore-size sieve and transferred to $15-\mathrm{ml}$ polypropylene tubes. A cushion of $0.6 \mathrm{M}$ sucrose was added to each tube, and the protoplasts were spun at $1,200 \times g$ at room temperature for $5 \mathrm{~min}$ in a swinging-bucket rotor. The interface was transferred to a new $15-\mathrm{ml}$ tube and protoplasts were centrifuged as mentioned above. The pellet was resuspended and washed two times in $8 \%$ mannitol, $4 \mathrm{mM} \mathrm{CaCl}_{2}, 80 \mathrm{mM}$ $\mathrm{KCl}$, and $2 \mathrm{mM} \mathrm{Na}_{2} \mathrm{PO}_{4}, \mathrm{pH}$ 7.2. Transfection of protoplasts with in vitro-transcribed viral RNA was performed in a commercial electroporator (Gene Pulser; BioRad) set at $0.16 \mathrm{kV}$ and $125 \mu \mathrm{FD}$. Electroporation was conducted in $8 \%$ mannitol, $80 \mathrm{mM} \mathrm{KCl}, 4 \mathrm{mM} \mathrm{CaCl}$, and $2 \mathrm{mM} \mathrm{Na}_{2} \mathrm{PO}_{4}, \mathrm{pH}$ 7.0, using 0.2 -cm-wide cuvettes and about $3 \times 10^{5}$ cells per reaction. Samples were placed at $0^{\circ} \mathrm{C}$ for $5 \mathrm{~min}$ and then resuspended in $1 \mathrm{ml}$ of $9 \%$ mannitol and $3 \%$ sucrose for 24 to $48 \mathrm{~h}$. Alternatively, a tobacco BY-2 cell suspension was used as a source to produce protoplasts. The cell suspension was centrifuged at $100 \times g$ for $5 \mathrm{~min}$ and the pellet was then washed with PIM

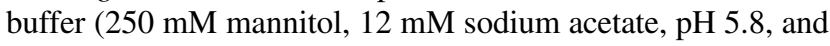
$50 \mathrm{mM} \mathrm{CaCl}_{2}$ ). Cells were incubated for 3 to $4 \mathrm{~h}$ in the same buffer supplemented with $10 \mathrm{mg}$ of cellulase R10 per $\mathrm{ml}$ and 1 $\mathrm{mg}$ of pectolyase Y23 per ml (Seishin Pharmaceutical, Tokyo, Japan). The protoplasts were filtered through a $300-\mu \mathrm{m}$ mesh; collected by centrifugation; washed three times with PIM buffer; and resuspended in $200 \mathrm{mM}$ mannitol, $150 \mathrm{mM} \mathrm{NaCl}$, $5 \mathrm{mM} \mathrm{CaCl}_{2}$, and $10 \mathrm{mM}$ HEPES, $\mathrm{pH}$ 7.2. Electroporation with infectious PVX transcripts was conducted in 0.4-cm-wide cuvettes at $0.15 \mathrm{kV}$ and $250 \mu \mathrm{FD}$, using about $1 \times 10^{6}$ cells per reaction. For recovery, protoplasts were placed at $0^{\circ} \mathrm{C}$ for 5 min and then kept for 24 to $48 \mathrm{~h}$ at room temperature in $3 \%$ sucrose; $4.3 \mathrm{~g}$ of Murashige-Skoog salts per liter; $1 \mathrm{mg}$ of thiamine- $\mathrm{HCl}$ per $\mathrm{ml} ; 0.2 \mathrm{mg}$ of 2,4-dichlorophenoxyacetic acid per liter; $100 \mathrm{mg}$ of inositol per $\mathrm{ml}, \mathrm{pH} 5.7$; and $0.2 \mathrm{M}$ mannitol.

\section{Western blot and ELISA.}

For Western blot analysis, $200 \mathrm{mg}$ of tobacco leaves was ground in liquid $\mathrm{N}_{2}$; homogenized in $200 \mu \mathrm{l}$ of $100 \mathrm{mM}$ Tris$\mathrm{HCl}, \mathrm{pH}$ 6.8, $10 \mathrm{mM}$ EDTA, and 1\% SDS; boiled for $5 \mathrm{~min}$; and centrifuged at $10,000 \times g$ for $15 \mathrm{~min}$ at $4^{\circ} \mathrm{C}$. Supernatant was transferred to new tubes and thoroughly mixed with four volumes of cold acetone. After incubation for $2 \mathrm{~min}$ at $0^{\circ} \mathrm{C}$, samples were centrifuged again and the pellet was resuspended in homogenization buffer. Protein content was determined by the bicinchoninic acid method (Smith et al. 1985) using a commercial system (Pierce Chemical, Rockford, IL, U.S.A.), and aliquots containing equivalent amounts $(20$ to $50 \mu \mathrm{g})$ of soluble protein were mixed with loading buffer $(1: 1, \mathrm{vol} / \mathrm{vol})$, boiled for $3 \mathrm{~min}$, subjected to electrophoresis in polyacryamideSDS gels, and transferred to nitrocellulose membranes (GibcoBRL). PVX was detected with rabbit antibodies raised against purified virions obtained from IFFIVE-INTA (Córdoba, Argentina). Specifically bound antibodies were visualized by incubation with alkaline phosphatase-linked goat anti-rabbit antibodies, followed by a chromogenic reaction using nitroblue tetrazolium and 5-bromo-4-chloro-3-indolyl phosphate (Promega) as substrates. ELISAs for PVX detection were performed with antibodies specifically recognizing the viral $\mathrm{CP}$ (PVX detection kit; Boehringer, Mannheim, Germany) following the manufacturer's instructions.

\section{Microscopical observations.}

Tobacco leaf samples of about $1 \times 1 \mathrm{~mm}$ were fixed with $2.5 \%$ glutaraldehyde in $0.1 \mathrm{M}$ phosphate buffer, $\mathrm{pH} 6.8$, for $2 \mathrm{~h}$ at room temperature. The tissue was washed three times with phosphate buffer and then postfixed with $1 \% \mathrm{OsO}_{4}$ for 1 to $2 \mathrm{~h}$ at $4{ }^{\circ} \mathrm{C}$. After three more washes, samples were dehydrated by successive treatments (30 min each) with 50, 60, 70, and 90\% ethanol, and subsequently embedded in LR white resin (Polyscience, Warrington, PA, U.S.A.). Alternatively, dehydration was conducted in a series of ethanol/propylene $(3: 1,1: 1$, and $1: 3)$, followed by a final treatment with propylene oxide and subsequently embedded in Spur's resin (Polyscience). Thin sections for observation under the light microscope were prepared using a Ultracut.E microtome (Reichert-Jung, Heidelberg, Germany). For detection of callose and lignin, affected areas of fresh leaves were cut in small pieces and incubated with either Aniline Blue, as a marker for $\beta$-(1-3)-D-glucans, or Safranine O, for staining of lignin, using the procedures described by O'Brien and McCully (1981) and Fulcher (1982). The Aniline Blue reaction was visualized with a Zeiss epifluorescent microscope provided with a III RS epi-illuminating condenser and a combination comprising filters 365 and 418 as exciter and barrier filters (Zeiss, Oberkochen, Germany). The two dyes were used separately or simultaneously. Production of phenolic compounds in leaf cuts was observed at $365 \mathrm{~nm}$ in a UV Image Master transilluminator (Amersham Pharmacia, Piscataway, NJ, U.S.A.).

\section{ACKNOWLEDGMENTS}

This work was supported by Grant 2851/98-4 of CONICET (Argentina). K. Kobayashi is a fellow of FOMEC/FCEN-UBA. S. Cabral, S. Maldonado, and A. Mentaberry are professional technician and research scientists of CONICET (Argentina), respectively. G. Calamante is a research scientist of INTA (Argentina). We thank F. Bravo-Almonacid for his valuable advice during this work and $\mathrm{X}$. Ares for providing the p12/p8 construction.

\section{LITERATURE CITED}

An, G., Ebert, P. R., Mitra, A., and Ha, S. M. 1988. Binary vectors. Section A3. Pages 1-19 in: Plant Molecular Biology Manual. S. B. 
Gelvin and R. A. Schilperoort, eds. Kluwer Academic, Dordrecht, the Netherlands.

Angell, S. M., Davies, C., and Baulcombe, D. C. 1996. Cell-to-cell movement of potato virus $\mathrm{X}$ is associated with a change in the sizeexclusion limit of plasmodesmata in trichome cells of Nicotiana clevelandii. Virology 216:197-201.

Ares, X., Calamante, G., Cabral, S., Lodge, J., Hemenway, P., Beachy, R. N., and Mentaberry, A. 1998. Transgenic plants expressing Potato virus $X$ ORF2 protein (p24) are resistant to Tobacco mosaic virus and Ob tobamoviruses. J. Virol. 72:731-738.

Beck, D. L., Guilford, P. J., Voot, D. M., Andersen, M. T., and Forster, R. L. 1991. Triple gene block proteins of White clover mosaic potexvirus are required for transport. Virology 183:695-702.

Beck, D. L., Van Dolleweerd, C. J., Lough, T. J., Balmori, E., Voot, D. M., Andersen, M. T., O'Brien, I. E., and Forster, R. L. 1994. Disruption of virus movement confers broad-spectrum resistance against systemic infection by plant viruses with a triple gene block. Proc. Natl. Acad. Sci. U.S.A. 91:10310-10314.

Bleykasten-Grosshans, C., Guilley, H., Bouzoubaa, S., Richards, K. E., and Jonard, G. 1997. Independent expression of the first two triple gene block proteins of beet necrotic yellow vein virus complements virus defective in the corresponding gene but expression of the third protein inhibits viral cell-to-cell movement. Mol. Plant-Microbe Interact. 10:240-246.

Bol, J. F., Linthorst, H. J. M., and Cornelissen, B. J. C. 1990. Plant pathogenesis-related proteins induced by virus infection. Annu. Rev. Phytopathol. 28:113-138.

Brederode, F. T., Linthorst, H. J. M., and Bol, J. F. 1991. Differential induction of acquired resistance and PR gene expression in tobacco by virus infection, ethephon treatment, UV light and wounding. Plant Mol. Biol. 17:1117-1125.

Calamante, G. 1998. Utilización del virus X de la papa como vector de expresión transitoria en plantas. Doctoral thesis. University of Buenos Aires, Buenos Aires.

Carrington, J. C., Kasschau, K. D., Mahajan, S. K., and Schaad, M. C. 1996. Cell-to-cell and long-distance transport of viruses in plants. Plant Cell 8:1669-1681.

Chang, B. Y., Lin, N. S., Liou, D. Y., Chen, J. P., Liou, G. G., and Hsu, Y. H. 1997. Subcellular localization of the $28-\mathrm{kDa}$ protein of the triple-gene-block of Bamboo mosaic potexvirus. J. Gen. Virol. 78:11751179.

Chapman, S., Kavanagh, T., and Baulcombe, D. 1992. Potato virus $X$ as a vector for gene expression in plants. Plant J. 2:549-557.

Davies, C., Hills, G., and Baulcombe, D. C. 1993. Sub-cellular localization of the 25-kDa protein encoded in the triple gene block of Potato virus $X$. Virology 197:166-175.

Deom, C. M., Lapidot, M., and Beachy, R. N. 1992. Plant virus movement proteins. Cell 69:221-224.

Erhardt, M., Stussi-Garaud, C., Guilley, H., Richards, K. E., Jonard, G., and Bouzoubaa, S. 1999. The first triple gene block protein of Peanut clump virus localizes to the plasmodesmata during virus infection. Virology 264:220-229.

Forster, R. L. S., Bevan, M. W., Harbison, S., and Gardner, R. C. 1988. The complete sequence of the White clover mosaic potexvirus. Nucleic Acids Res. 16:291-304.

Forster, R. L., Beck, D. L., Guilford, P. J., Voot, D. M., Van Dolleweerd, C. J., and Andersen, M. T. 1992. The coat protein of White clover mosaic potexvirus has a role in facilitating cell-to-cell transport in plants. Virology 191:480-484.

Fulcher, R. G. 1982. Fluorescence microscopy of cereals. Food Microstructure 1:167-175.

Gorbalenya, A. E., Koonin, E. V., Donchenko, A. P., and Blinov, V. M. 1988. A novel superfamily of nucleoside triphosphate-binding motif containing proteins which are probably involved in duplex unwinding in DNA and RNA replication and recombination. FEBS (Fed. Eur. Biochem. Soc.) Lett. 235:16-24.

Hefferon, K. L., Doyle, S., and AbouHaidar, M. G. 1997. Immunological detection of the $8 \mathrm{~K}$ protein of Potato virus $X$ (PVX) in cell walls of PVX-infected tobacco and transgenic potato. Arch. Virol. 142:425433.

Kalinina, N. O., Fedorkin, O. N., Samuilova, O. V., Maiss, E., Korpela, T., Morozov, S., and Atabekov, J. G. 1996. Expression and biochemical analyses of the recombinant Potato virus $X 25 \mathrm{~K}$ movement protein. FEBS (Fed. Eur. Biochem. Soc.) Lett. 397:75-78.
Koonin, E. V., and Dolja, V. V. 1993. Evolution and taxonomy of positive-strand RNA viruses: Implications of comparative analysis of amino acid sequences. Crit. Rev. Biochem. Mol. Biol. 28:375-430.

Lough, T. J., Shash, K., Xoconostle-Cázares, B., Hofstra, K. R., Beck, D. L., Balmori, E., Forster, R. L. S., and Lucas, W. J. 1998. Molecular dissection of the mechanism by which potexvirus triple gene block protein mediate cell-to-cell transport of infectious RNA. Mol. PlantMicrobe Interact. 11:801-814.

Lough, T. J., Netzler, N. E., Emerson, S. J., Sutherland, P., Carr, F., Beck, D. L., Lucas, W. J., and Forster, R. L. S. 2000. Cell-to-cell movement of potexviruses: Evidence for a ribonucleoprotein complex involving the coat protein and first triple gene block protein. Mol. Plant-Microbe Interact. 13:962-974.

Lucas, W. J., and Wolf, S. 1999. Connections between virus movement, macromolecular signaling and assimilate allocation. Curr. Opin. Plant Biol. 2:192-197.

Malcuit, I., Marano, M. R., Kavanagh, T. A., DeJong, W., Forsynth, A., and Baulcombe, D. C. 1999. The 25-kDa movement protein of PVX elicits $N b$-mediated hypersensitive cell death in potato. Mol. PlantMicrobe Interact. 12:536-543.

Meshi, T., Motoyoshi, F., Maeda, T., Yoshiwoka, S., Watanabe, H., and Okada, Y. 1989. Mutations in the Tobacco mosaic virus $30-\mathrm{kD}$ protein gene overcome Tm-2 resistance in tomato. Plant Cell 1:515-522.

Morozov, S., Lukasheva, L. I., Chernov, B. K., Skryabin, K. G., and Atabekov, J. G. 1987. Nucleotide sequence of the open reading frames adjacent of the coat protein cistron in Potato virus $X$ genome. FEBS (Fed. Eur. Biochem. Soc.) Lett. 213:438-442.

Morozov, S., Dolja, V. V., and Atabekov, J. G. 1989. Probable reassortment of genomic elements among elongated RNA-containing plant viruses. J. Mol. Evol. 29:52-62.

Morozov, S. Y., Miroshnichenko, N. A., Zelenina, D. A., Fedorkin, O. N., Solovijev, A. G., Lukasheva, L. I., and Atabekov, J. C. 1990. Expression of RNA transcripts of Potato virus $X$ full-length and subgenomic cDNAs. Biochimie 72:677-684.

Morozov, S., Miroshnichenko, N. A., Solovyev, A. G., Fedorkin, O. N., Zelenina, D. A., Lukasheva, L. I., Karasev, A. V., Dolja, V. V., and Atabekov, J. G. 1991a. Expression strategy of the Potato virus X triple gene block. J. Gen. Virol. 72:2039-2042.

Morozov, S., Miroshnichenko, N. A., Solovyev, A. G., Zelenina, D. A., Fedorkin, O. N., Lukasheva, L. I., Grachev, S. A., and Chernov, B. K. 1991b. In vitro membrane binding of the translation products of the Carlavirus $7 \mathrm{kDa}$ protein genes. Virology 183:782-785.

Morozov, S., Fedorkin, O. N., Juttner, G., Schiemann, J., Baulcombe, D. C., and Atabekov, J. G. 1997. Complementation of a Potato virus X mutant mediated by bombardment of plant tissues with cloned viral movement protein genes. J. Gen. Virol. 78:2077-2083.

Mushegian, A. R., and Koonin, E. V. 1993. Cell-to-cell movement of plant viruses. Insights from amino acid sequence comparisons of movement proteins and from analogies with cellular transport systems. Arch. Virol. 133:239-257.

O'Brien, T. P., and McCully, M. E. 1981. The Study of Plant Structure: Principles and Selected Methods. Thermocarphy Pty. Lds., Melbourne, Australia.

Oparka, K. J., Roberts, A. G., Roberts, I. M., Prior, D. A., and Santa Cruz, S. 1996. Viral coat protein is targeted to, but does not gate, plasmodesmata during cell-to-cell movement of Potato virus X. Plant J. 10:805-813.

Orman, B. E., Celnik, R. M., Mandel, A. M., Torres, H. N., and Mentaberry, A. N. 1990. Complete cDNA sequence of a South American isolate of Potato virus X. Virus Res. 16:293-305.

Padgett, H. S., and Beachy, R. N. 1993. Analysis of a Tobacco mosaic virus strain capable of overcoming $N$ gene-mediated resistance. Plant Cell 5:577-586.

Ponz, F., and Bruening, G. 1986. Mechanisms of resistance to plant viruses. Annu. Rev. Phytopathol. 24:355-383.

Ross, A. F. 1961. Systemic acquired resistance induced by localized virus infections in plants. Virology 14:340-358.

Rouleau, M., Smith, R. J., Bancroft, J. B., and Mackie, G. A. 1994. Purification, properties and subcellular localization of Foxtail mosaic potexvirus 26-kDa protein. Virology 204:254-265.

Ruiz, M. T., Voinnet, O., and Baulcombe, D. C. 1998. Initiation and maintenance of virus-induced gene silencing. Plant Cell 10:937-946.

Ryals, J. A., Neuenschwander, U. H., Willits, M. G., Molina, A., Steiner, H. Y., and Hunt, M. D. 1996. Systemic acquired resistance. Plant Cell 
8:1809-1819.

Santa Cruz, S., Roberts, A. G., Prior, D. A., Chapman, S., and Oparka K. J. 1998. Cell-to-cell and phloem-mediated transport of Potato virus $X$. The role of virions. Plant Cell 10:495-510.

Seppanen, P., Puska, R., Honkanen, J., Tyulkina, L. G., Fedorkin, O., Morozov, S., and Atabekov, J. G. 1997. Movement protein-derived resistance to triple gene block-containing plant viruses. J. Gen. Virol 78:1241-1246.

Skryabin, K. G., Morozov, S., Kraev, A. S., Rozanov, M. N., Chernov, B K., Lukasheva, L. I., and Atabekov, J. G. 1988. Conserved and variable elements in RNA genomes of Potexviruses. FEBS (Fed. Eur. Biochem. Soc.) Lett. 240:33-40.

Smith, P. K., Krohn, R. I., Hermanson, G. T., Mallia, A. K., Gartner, F. H., Provenzano, M. D., Fujimoto, E. K., Goeke, N. M., Olson, B. J., and Klenck, D. C. 1985. Measurement of protein using bicinchoninic acid. Anal. Biochem. 150:76-85.

Solovyev, A. G., Stroganova, T. A., Zamiatnin, A. A., Jr., Fedorkin, O.
N., Schiemann, J., and Morozov, S. Y. 2000. Subcellular sorting of small membrane-associated triple gene block proteins: TGBp3-assisted targeting of TGBp2. Virology 269:113-127.

Verchot, J., Angell, S. M., and Baulcombe, D. C. 1998. In vivo translation of the triple gene block of Potato virus $X$ requires two subgenomic mRNAs. J. Virol. 72:8316-8320.

Verwoerd, T., Dekekr, B., and Hoekema, A. 1989. A small-scale procedure for the rapid isolation of plant RNAs. Nucleic Acids Res. 17: 2362 .

Weber, H., and Pfitzner, A. J. P. 1998. Tm- $2^{2}$ resistance in tomato requires recognition of the carboxy terminus of the movement protein of tomato mosaic virus. Mol. Plant-Microbe Interact. 11:498-503.

Yang, Y., Ding, B., Baulcombe, D. C., and Verchot, J. 2000. Cell-to-cell movement of the $25 \mathrm{~K}$ protein of Potato virus $X$ is regulated by three other viral proteins. Mol. Plant-Microbe Interact. 13:599-605.

Zhou, H., and Jackson, A. O. 1996. Expression of the Barley stripe mosaic virus RNA $\beta$ “triple gene block." Virology 216:364-379. 